ISSN 1392-3196 / e-ISSN 2335-8947

Zemdirbyste-Agriculture, vol. 100, No. 3 (2013), p. 269-276

DOI $10.13080 / \mathrm{z}-\mathrm{a} .2013 .100 .034$

\title{
The force needed for breaking and cutting of winter wheat and spring barley straw
}

\author{
Egidijus ŠARAUSKIS ${ }^{1}$, Laura MASILIONYTE் ${ }^{1,2}$, Albinas ANDRIUŠIS ${ }^{1}$, Antanas JAKŠTAS ${ }^{1}$ \\ ${ }^{1}$ Aleksandras Stulginskis University \\ Studentu 11, Akademija, Kaunas distr., Lithuania \\ E-mail: egidijus.sarauskis@asu.lt \\ ${ }^{2}$ Joniškèlis Experimental Station, Lithuanian Research Centre for Agriculture and Forestry \\ Joniškèlis, Pasvalys distr., Lithuania \\ E-mail: laura.masilionyte@gmail.com
}

\begin{abstract}
When applying soil, environment and energy sustaining tillage and drilling technologies, cultivation and seed incorporation become more complex. Crop residues left on the soil surface have a considerable influence on the process of tillage and drilling machinery operation. They aggravate the operation of tillage and especially that of drill coulters. Most often soil, environment and energy sustaining tillage and drilling technologies use disc coulters which can cut, break or press crop residues into the notch made by the coulter in the soil while interacting with the soil surface. The objective of this work is to investigate the forces of breaking or cutting fresh or overwintered straw of winter wheat and spring barley influencing the process of tillage and drilling machinery operation.

Research on cutting and breaking crop residues was carried out during the period of 2011-2012 in the Tribology Laboratory of Aleksandras Stulginskis University. The fresh straw of winter wheat and spring barley of $22 \%$ moisture content and overwintered straw of $5 \%$ moisture content with nodes and without nodes were used for the research.

Our research evidenced that the crop residues of spring barley were easier to break compared with those of winter wheat. About $160 \mathrm{~N}$ force is needed to break fresh straw of winter wheat with nodes or without them compared with the analogous type of spring barley straw - about $53 \mathrm{~N}$ force. Great influence on breaking characteristics is made by leaving the crop residues to overwinter on the soil surface. However, the research showed that the characteristics of the winter wheat and spring barley crop residues left to overwinter vary unevenly. The force for breaking the overwintered winter wheat straw decreases by about 3.2 times compared with the fresh straw of winter wheat and the force for breaking the straw of overwintered spring barley decreases by $34 \%$. The research on cutting crop residues with a knife simulating a disc coulter showed that the cutting of the fresh and overwintered crop residues of winter wheat and spring barley at the node and other section of the straw differs signally. In order to cut the fresh straw of winter wheat and spring barley at the node 35 to $43 \mathrm{~N}$ weaker force is required compared to cutting at other sections of the straw. To cut the overwintered straw of spring barley and winter wheat at the node $18 \%$ to $30 \%$ weaker force is required compared with the fresh straw. During the cutting at the node the straw of winter wheat and spring barley is deformed less and more slowly compared to solid straw without nodes.
\end{abstract}

Key words: breaking force, coulter, crop residues, cutting force, spring barley, winter wheat.

\section{Introduction}

The development of soil, environment and energy-sustaining tillage technologies is one of the most important goals of the modern agricultural advancement. While introducing sustainable agricultural technologies the soil structure and its phytosanitary condition are improved, plant residues are used efficiently for fertilization and soil protection, precision tillage machines are applied which reduce the negative impact of technological operational processes on the soil and environment; labour, energy and agricultural production costs are reduced (Hazarika et al., 2009; Fan et al., 2012).

The major share of energy costs in traditional agriculture (up to 30\%) is taken by soil tillage (Bakasènas,
2008; Germanas, 2008). The greatest influence on energy consumption of agricultural machinery is exerted by the design and technology parameters of a machine's working parts, conditions of tillage technological operation (working depth, intensity of soil loosening, driving speed, etc.) and physical and mechanical characteristics of soil such as soil moisture, bulk density, penetration resistance, soil texture, etc. that the forces required for penetrating of tillage machinery working parts and pulling them depend on. Crop residues left on the soil surface and their physical and biological characteristics have a marked impact on the work quality of tillage and drilling machinery. Tillage and drilling machinery with regular 
coulters often clogs up, the quality of soil bed preparation decreases and labour time consumption costs increase when the soil is amply covered with the crop residues of grain crops (Arvidsson et al., 2004; Arvidsson, 2010; Šarauskis et al., 2012).

Whenintroducingsustainabletillagetechnologies it is very important that the crop harvest residues are chopped into small pieces and evenly distributed on the soil surface. The length of crop harvest residues and the evenness of their distribution on the soil surface depend on the design and calibration of the harvester chopper. The greater part of the crop harvest residues is chopped in chaff shorter than $5 \mathrm{~cm}$ and the more even the crop harvest residues are distributed over the entire working width of the harvester's cutterbar, the less influence these residues make on the working parts' operation quality of shallow tillage and drilling machinery (Kushwaha et al., 1986; O’Dogherty et al., 1995; Arvidsson et al., 2004; Arvidsson, 2010).

To till and drill the soil with abundant crop residues on the surface the machinery with disc working parts are commonly used. Theoretical and experimental research established that a disc coulter penetrates and cuts the soil while rotating around its axis. Along its way the coulter meets crop residues which it can cut, run over them or start pushing them forward. During the working process the disc coulter cuts or runs over the crop residues on its way; they are pressed between the cutting edge of the coulter and the soil surface. The pressure on crop residues depends on the angle of nipping between the coulter and the soil surface (Magalhaes et al., 2007; Šarauskis, 2008). When crop residues are distributed unevenly, in thicker or thinner layers, disc coulters cannot always press the crop residues between the coulter cutting edge and the soil surface. In such cases the coulter clogs up and pushes the crop residues in front of it. Theoretically, crop residues are cut or pressed into the soil when the direction of pressure force action is within the limits of a friction angle between the crop residues and the soil surface. In order to avoid crop residues to be pushed along the soil surface the disc coulters of a larger diameter or serrated cutting edges are fixed (Kushwaha et al., 1986; Šarauskis et al., 2005).

The researchers from different countries of the world carried out the investigations of the mechanical characteristics of different plants, e.g., chopping of alfalfa biomass (Galedar et al., 2008), cumin cutting (Mahmoodi, Jafari, 2010), influence of sunflower stems on the operation of disc coulters (Ince et al., 2005) and cutting of cereal straw (Linke, 2006). The majority of authors observed that the cutting force required to cut through crop residues depended on the plant species, moisture, stem diameter, plant length, cell structure and elasticity, resistance to compression, bending, snipping and cutting (Tavakoli et al., 2009). The design parameters, shape, angle of attack, working depth and speed of movement of a disc coulter have great importance to the cutting of crop residues as well (Liu et al., 2007; 2010). Linke (2006) suggests that the mechanical characteristics of crop residues (cutting, snipping, etc.) depend a lot on the time that the crop residues are left on the soil surface. If crop residues are left on the soil surface for a long time, their characteristics change and less power is required to cut them compared with fresh crop residues.

The cutting process of crop residues on the soil surface depends highly on the soil physical and mechanical characteristics. The crop residues on the moist soil of low penetration resistance are left uncut most often; they are only pressed into the notch made by a disc coulter. The cutting edge of the disc coulter can cut crop residues only in such cases when the penetration resistance of soil is higher than the normal stresses of straw (Kushwaha et al., 1986; Šarauskis et al., 2005).

Recently an increasing scale of the working parts of tillage and drilling machinery has shown that it is complicated to avoid the interference by crop residues. Therefore, double disc coulter can be used or special disc-shaped cleaners for removing crop residues can be mounted before coulters. Double disc coulters consisting of two discs with $5 \mathrm{~mm}$ or a larger space between them can cut the same crop residue (e.g., straw) in two different sections. In certain cases one disc can be shifted with regard to the other disc. When meeting crop residues the cutting edge of the disc shifted to the front presses them to the soil surface. Depending on the characteristics of the soil and crop residues they can be cut or pressed into the soil. While disc coulters are moving forward, the same crop residues are pressed to the soil by the cutting edge of the second disc which can also cut the crop residues or press them into the soil. While penetrating the soil at the same time the disc coulters can both cut the crop residues and drag them along the soil surface curved outwards between the discs. The soil resists the penetration of the crop residues; therefore, they can be broken, if the stress on the crop residues is exceeded. If the number of indentations in the cutting edges of both discs is equal, crop residues can enter the indentations of both discs at the same time. In such a case the crop residues will be dragged for a shorter time and can remain unbroken. A different number of indentations in the cutting edges of the discs can reduce the probability that crop residues enter the indentations of both disc cutting edges at the same time. The shift of the first disc to the front with regard to the second one has to be lesser than $1 / 2$ of the length of the disc section that enters the soil. If the shift is bigger than that, the discs will cut crop residues as single disc coulters (Šarauskis et al., 2005; Sarauskis, 2008).

Taking into consideration the literature analysis presented above and considering that climatic conditions and plant characteristics in different countries of the world differ greatly the following objective was pursued: to investigate the characteristics of breaking and cutting the straw of fresh straw and overwintered winter wheat and spring barley influencing the working process of tillage and drilling machinery coulters under the climatic conditions in our region.

\section{Materials and methods}

The experimental research on the characteristics of crop residues was carried out in the period of 20112012 in the Tribology Laboratory, Faculty of Agricultural Engineering of Aleksandras Stulginskis University. The straw of winter wheat (Hordeum vulgare L.) cv. 'Ada' and spring barley (Triticum aestivum L.) cv. 'Simba' grown under conventional cropping system was used for the research; the samples were taken from the plots of the University's Trial Station. The straw samples collected were weighed, distributed evenly and dried in a dessicator at $105^{\circ} \mathrm{C}$ temperature before their mass reached constant weight. Then, having evaluated the 
straw mass before drying and after it straw moisture was calculated. The straw of winter wheat (Fig. 1 a) and spring barley (Fig. 1 b) of $22 \%$ moisture content cut fresh during harvest (hereinafter referred to as fresh straw) and that of 5\% moisture content left on the soil surface through winter was used for the experimental research. The experimental research was carried out with the straw of $80 \mathrm{~mm}$ in length divided in two batches: $80 \mathrm{~mm}$ long stems without nodes and $120 \mathrm{~mm}$ long stems with nodes (Pic. 1).

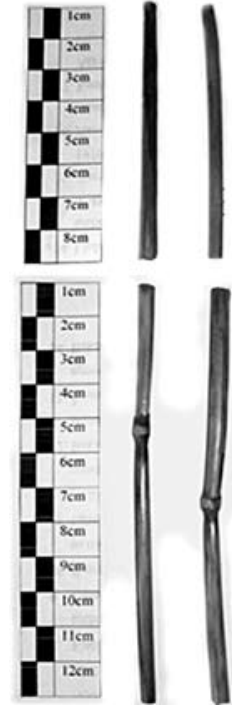

a)
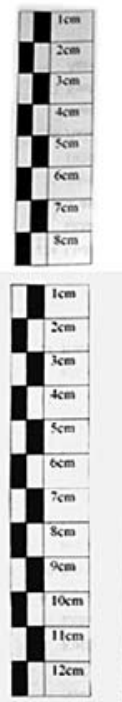

b)
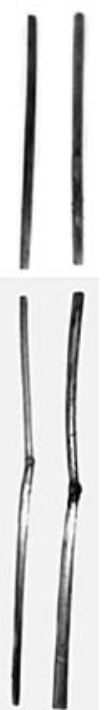

)
Picture 1. Straw used for the experiments: a - winter wheat, $\mathrm{b}$ - spring barley

Experimental procedures. Establishment of tension (breaking) force. Tribometer TRM 500 (Wazau $\mathrm{GmbH}$, Germany) was used to establish the breaking force of crop harvest residues (Pic. 2). In order to apply it in the experiments with crop harvest residues a special device allowing fixing the examined crop residues from both ends was made.

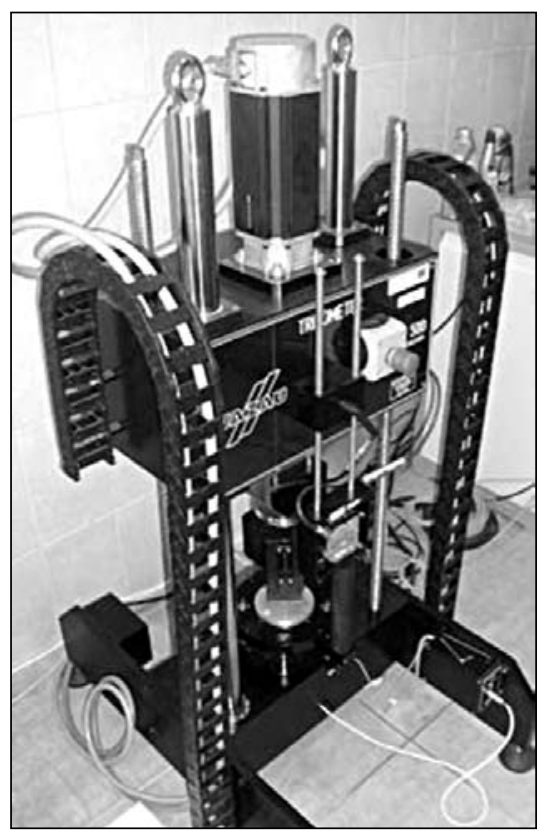

Picture 2. Instrument (tribometer TRM 500) used to investigate crop residue characteristics
In order to avoid breaking of crop residues at the points of their grip, special preparation of the straw for fixing was arranged. Tiny $15 \mathrm{~mm}$ long steel wires were stuck into both ends of straw stems corresponding to the internal diameter of a straw. Each end of the straw was wrapped with a $15 \mathrm{~mm}$ wide sand paper strip from the outside which ensured that the straw did not slip out from the device during the experiments. A small rubber tube was put on the abrasive paper and the straw 3 (Pic. 3) prepared in such a way was put into the apertures of the holders 2; it was fixed and held with the help of fasteners to have the axial line of the straw agree with the axial lines of the upper 5 and the lower 1 plates of the tribometer. One of the holders was tightly fixed to the lower immobile plate of the tribometer and the other was fixed to the upper plate which could move from top to bottom.

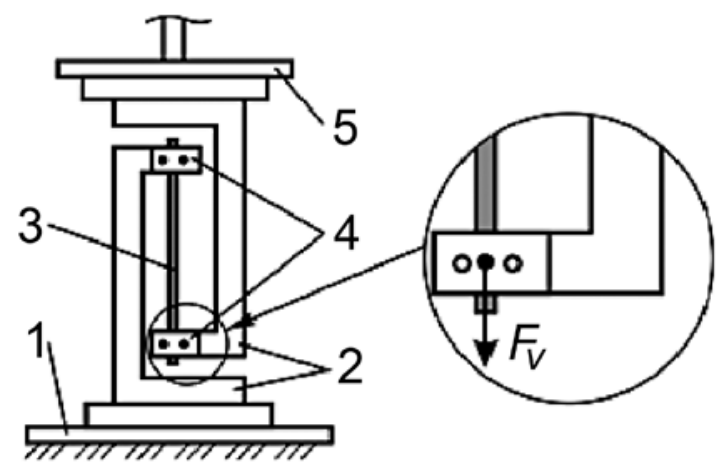

Picture 3. Device to perform experiments of crop residue breaking: 1 - lower plate, 2 - holder, 3 - straw, 4 facilities for fixing straw, 5 - upper plate; $F_{v}$ - vertical force, $\mathrm{N}$

The experiments of different variants of winter wheat and spring barley straw breaking force were carried out with five replications. TriboControl software created by the manufacturer of the tribometer was used to operate the instrument. To carry out the experiments the instrument was fixed in such a way that the upper plate 5 would move together with holder 2 vertically down until the examined straw broke. During the straw tension the variation (increase) rate of force $F$ was equal to $20 \mathrm{~N} \mathrm{~min}^{-1}$.

Establishment of cutting force. The research of cutting crop harvest residues was carried out using the same instrument (tribometer TRM 500) as in the research of breaking. With a view to obtaining as realistic operating conditions as possible knife 4 (Pic. 4) was produced of a disc coulter used in agricultural machinery. The knife was sharpened at an angle of $25^{\circ}$ and fixed in holder 5 . The holder with a tightly fixed knife was fastened to the upper plate 6 which could move vertically down. A small plastic retaining plate 2 was placed on the lower plate 1 , the plasticity of which allowed simulating the surface of very hard untilled soil. The examined straw without and with nodes was placed square to the knife edge. The straw with nodes was cut at the middle of the node. The same software TriboControl to operate the instrument was used as during the research of breaking. At the start of each separate experiment of straw cutting the knife was set on the surface of the straw and then pressed with a force whose variation (increase) rate was $-20 \mathrm{~N} \mathrm{~min}^{-1}$. The straw was acted on until it was cut. The obtained cutting data was saved in the computer memory. 


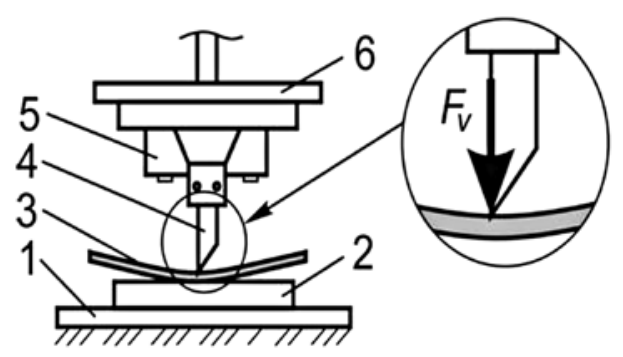

Picture 4. Device to perform experiments of crop residue cutting: 1 - lower plate, 2 - small plastic retaining plate, 3 - straw, 4 - knife, 5 - knife fixation holder, 6 - upper plate; $F v$-vertical force, $\mathrm{N}$

Straw deformation during cutting was established measuring the shift of plate 6 with regard to plate 1 . The deformation research was performed by a laser distance meter of the tribometer, the resolution of which was $1 \mu \mathrm{m}$. To assess the internal deformation of the very tribometer and the device (Pic. 4) during the experiment additional testing measurements were taken, when knife 4 was pressed with force $F_{v}$ from 0 to $200 \mathrm{~N}$ but without the straw. The obtained testing data of deformation was minute (about 4-5 $\mu \mathrm{m}$ ) compared with the deformations recorded during straw cutting. Therefore, in the further research the internal deformation of the device was not assessed.

Statistical analysis. The data of the experiments was analyzed by statistical - mathematical methods estimating the least significant difference $\mathrm{LSD}_{05}$ at 95\% probability level (Tarakanovas, Raudonius, 2003; Crawley, 2007).

\section{Results and discussion}

The experimental research established that the forces required to break the straw of winter wheat and spring barley cultivated under Lithuanian climatic conditions were unequal. The force required to break the straw of winter wheat without nodes has to be 3 times greater compared with the analogous straw of spring barley. On average the fresh straw of winter wheat without nodes was broken at $158.7 \mathrm{~N}$ and that of spring barley - at $53.7 \mathrm{~N}$ force (Fig. 5).

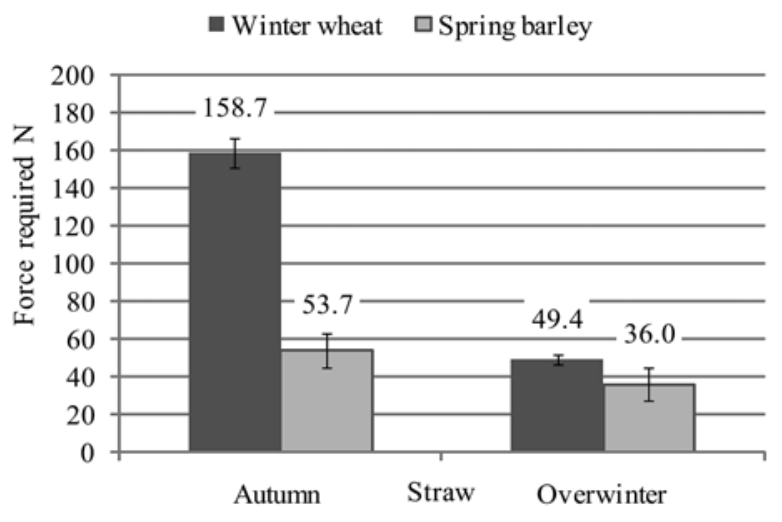

$\mathrm{LSD}_{05}$ winter wheat $-2.7, \mathrm{LSD}_{05}$ spring barley -9.0

Figure 5. Results of breaking force applied on fresh straw and overwintered winter wheat and spring barley without nodes
The difference between different plants was rather great and it is not easy to explain. One of the reasons could be that the spring barley straw was a little smaller compared with the winter wheat straw. Assessing the research by other authors it was observed that the quantities of certain materials differed in different types of straw (Grabber, 2005; Kriaučiūnienè et al., 2012) and that could also influence the resistance to straw breaking. The straw on the soil surface and that present in deeper layers of soil change their physical, mechanical and biological characteristics under the impact of environmental factors. The research established that the force required to break the straw of winter wheat which overwintered on the soil surface was significantly weaker $(49.4 \mathrm{~N})$ compared to fresh straw. Having carried out the research with the straw of spring barley it was established that the force required to break the overwintered straw of spring barley was significantly $33 \%$ weaker compared with the fresh straw of spring barley. The analogous research of the force required to break the fresh straw and overwintered winter wheat with nodes showed that the breaking force was very similar to that applied to break the straw of winter wheat without nodes. To break the fresh straw of winter wheat with nodes the average force required is $160.4 \mathrm{~N}$ and for the overwintered straw -49.3 $\mathrm{N}$ force (Fig. 6). Having carried out the research with the straw of spring barley with nodes it was established that the force required to break the fresh and overwintered straw was very similar to that required to break the spring barley straw without nodes. The experimental research proved that the nodes present in straw had no significant influence on the breaking characteristics of fresh and overwintered straw of winter wheat and spring barley.

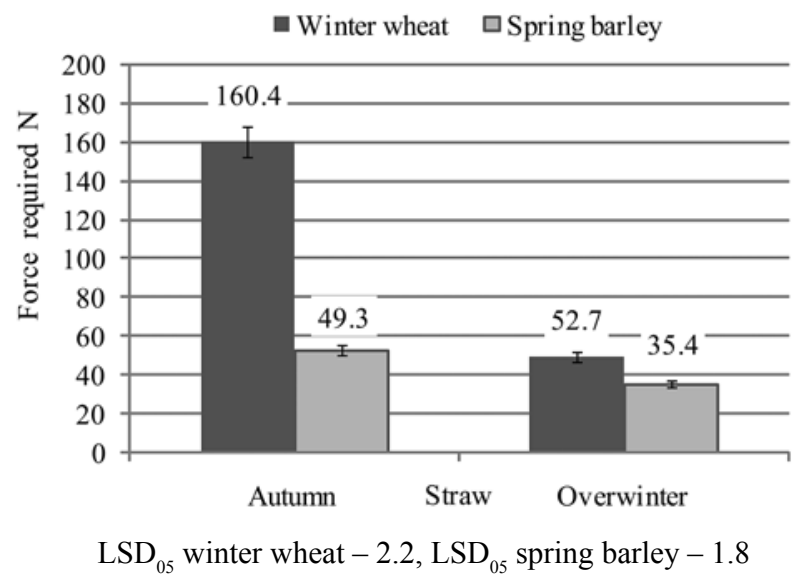

Figure 6. Results of breaking force applied on straw of fresh and overwintered winter wheat and spring barley with nodes

During the experimental research it was observed that the force for breaking the straw of overwintered winter wheat decreased significantly more than that of spring barley compared to the fresh straw. That could be influenced by the fact that the intensity of cereal straw fission was determined by the ratio of carbon and nitrogen, the amount of lignin in the organic matter and its minuteness (Kriaučiūnienè et al., 2012). The research established that there was $6 \%$ more carbon and $33 \%$ less of nitrogen in the straw of winter wheat compared with the straw of spring barley (Grabber, 2005; Kriaučiūnienè et al., 2012). 
Research of crop residue cutting. During the theoretical and experimental research carried out earlier (Šarauskis et al., 2005) it was established that the result of straw and disc coulter interaction was the compression of straw. When the straw normal stress is exceeded, the straw is cut. At that moment the force required to cut the straw has to be maximum, i.e. stronger than the forces of straw resistance. The cutting force depends on design parameters of a disc coulter, thickness of the straw cut, physical and mechanical characteristics and compression distance. As in real conditions straw is cut on the soil it is required to take account of the condition that the cutting edge of the disc coulter can cut the straw only in the situation, when soil penetration resistance is higher than the normal stress of the straw. Otherwise, the straw is pressed into the soil. Having carried out the experimental

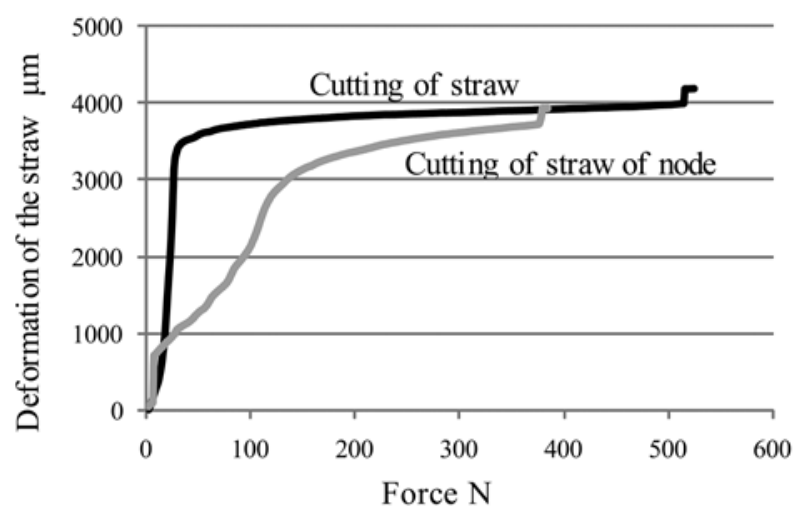

Figure 7. Cutting forces and deformations of fresh straw of winter wheat without and with nodes (LSD $_{05}$ cutting of straw -5.8 , cutting of straw of node -2.0 )

Having performed the research with the fresh straw of spring barley it was established that the force required to cut the stems of spring barley straw without nodes was equal to $117.2 \mathrm{~N}$ and the force for cutting the straw at the node was $77.2 \mathrm{~N}$ (Fig. 8). The force for cutting the fresh straw of spring barley without nodes was

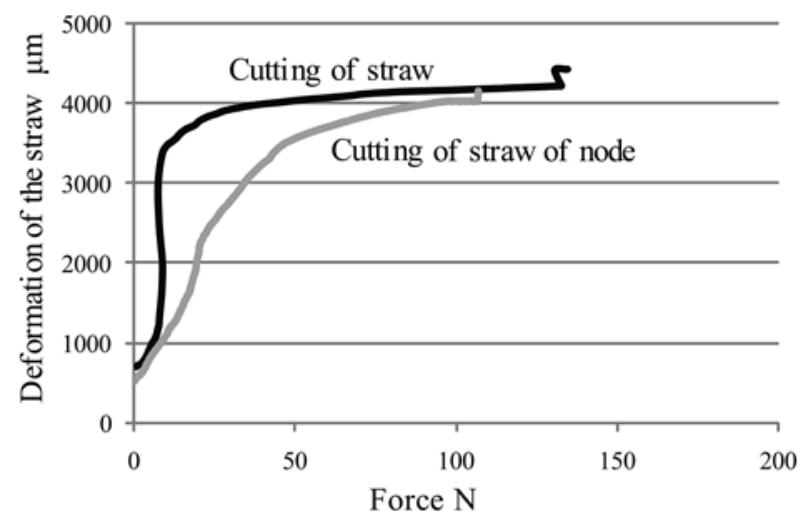

Figure 9. Cutting forces and deformations of overwintered straw of winter wheat without and with nodes $\left(\mathrm{LSD}_{05}\right.$ cutting of straw - 6.9, cutting of straw of node -3.3$)$

The forces of cutting the overwintered straw of spring barley without and with nodes were $99.8 \mathrm{~N}$ and $62.2 \mathrm{~N}$ respectively (Fig. 10). To cut the overwintered straw of spring barley at the node about $37 \%$ less force research the cutting force required to cut through the fresh and overwintered straw of winter wheat and spring barley was established. The research data showed that the forces for cutting the fresh straw of winter wheat without and with nodes and their deformations were not equal. To cut fresh straw of winter wheat without nodes $154.9 \mathrm{~N}$ force was required and to cut the straw with nodes - the average force of $123.7 \mathrm{~N}$ (Fig. 7). When investigating the straw deformations during cutting it was established that the straw of winter wheat deformed at the node more slowly compared to the straw without nodes. That shows structural changes in straw. At the start, a straw without a node is compressed more easily and with a weaker force and a straw node which contrary to the straw without nodes is made of certain vegetative matter is compressed with a stronger force in the beginning.

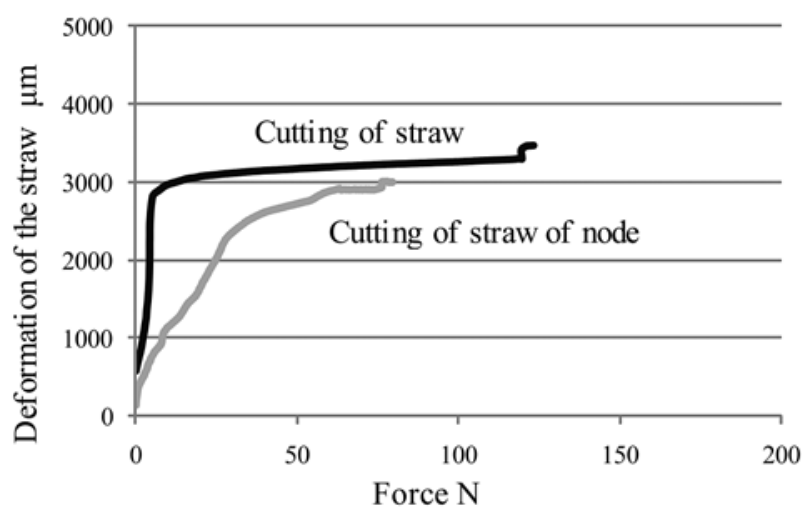

Figure 8. Cutting forces and deformations of fresh straw of spring barley without and with nodes $\left(\mathrm{LSD}_{05}\right.$ cutting of straw -13.7 , cutting of straw of node -2.1 )

1.5 times stronger compared to the force required to cut at the straw node. The analogous experimental research with the overwintered straw established that the force required to cut the straw of winter wheat without nodes was $134.8 \mathrm{~N}$ on average (Fig. 9) and to cut the same straw at the node $31.0 \%$ weaker force was enough $(94.2 \mathrm{~N})$.

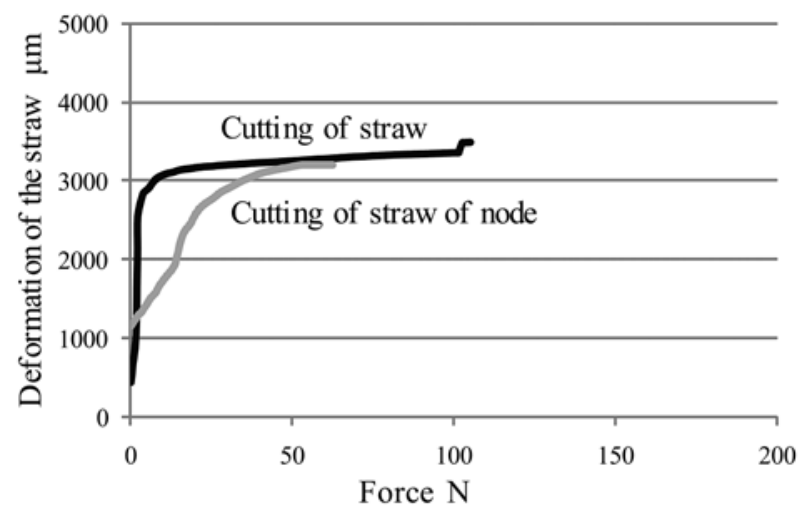

Figure 10. Cutting forces and deformations of overwintered straw of spring barley without and with nodes $\left(\mathrm{LSD}_{05}\right.$ cutting of straw - 11.4, cutting of straw of node -4.3 )

was required compared with another section of the straw. When cutting the overwintered straw of spring barley at the node the straw deformation during cutting was about $17 \%$ less compared with cutting at another section of the 
straw. The research made showed that leaving winter wheat and spring barley straw to overwinter on the soil surface had great influence both on straw breaking and cutting. To cut the overwintered straw of winter wheat about $13 \%$ less force was required compared with the fresh straw of winter wheat (Fig. 11). Even greater influence

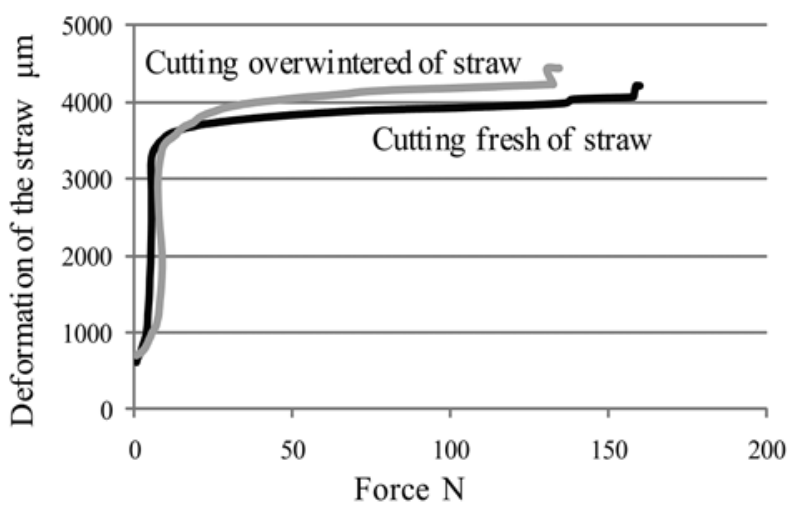

Figure 11. Cutting forces and deformations of fresh and overwintered straw of winter wheat LSD $_{05}$ cutting overwintered of straw -10.8 , cutting fresh straw - 10.8)

While comparing straw deformations during cutting, it was observed that the overwintered straw of winter wheat deformed $7 \%$ to $10 \%$ more compared with the fresh straw of winter wheat. To cut the fresh straw of spring barley about $17.4 \mathrm{~N}$ stronger force was needed compared to the overwintered straw of spring barley (Fig. 13). A similar tendency of cutting force difference was achieved having compared the research results of cutting the autumn and overwintered straw of spring

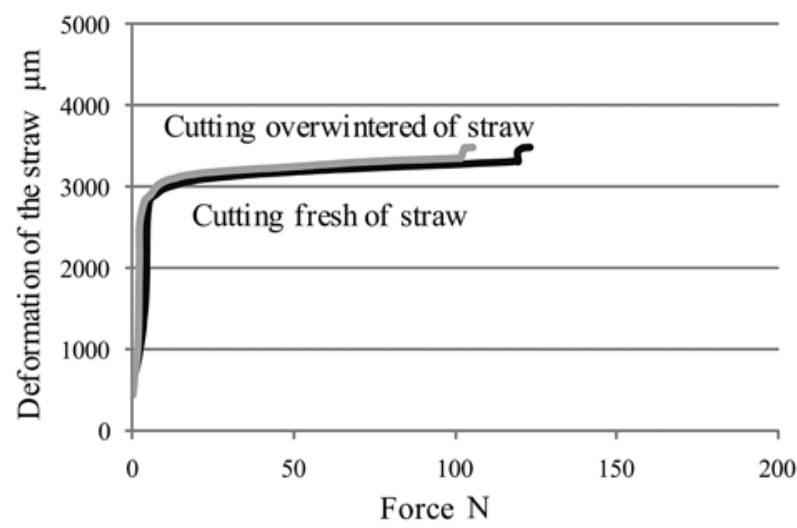

Figure 13. Cutting forces and deformations of fresh and overwintered straw of spring barley (LSD $_{05}$ cutting overwintered of straw -4.3 , cutting fresh of straw - 11.4)

Concluding the achieved results of the experimental research it can be stated that it is more complicated to carry out the minimum sustainable tillage or direct drilling into stubble in autumn, i.e. right after harvesting, compared to spring. That is because both to cut and break fresh crop residues of winter wheat and spring barley more force is required compared with the overwintered residues of these crops. The crop residues left to winter change their characteristics in interaction was established analyzing the research results of cutting the fresh and overwintered straw of winter wheat at the node. To cut the fresh straw of winter wheat at the node about $30 \%$ stronger force was needed compared to the overwintered straw (Fig. 12).

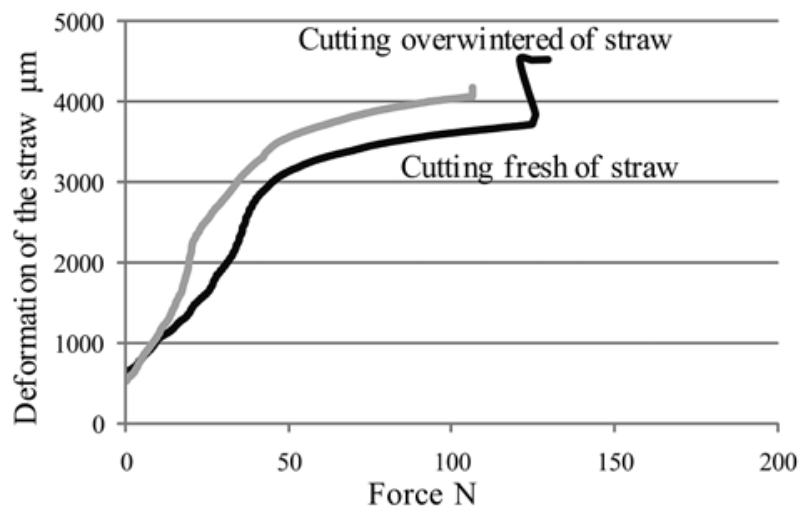

Figure 12. Cutting forces and deformations of fresh and overwintered straw of winter wheat at the node $\left(\mathrm{LSD}_{05}\right.$ cutting overwintered of straw -3.9 , cutting fresh straw - 15.8)

barley at the node. It was established that in order to cut the overwintered straw of spring barley at the node about $19 \%$ less force was required compared to the fresh straw of spring barley (Fig. 14). Contrary to the research of winter wheat straw the difference in deformations during cutting of the autumn and overwintered straw of spring barley without (Fig. 13) and with nodes (Fig. 14) was not established.

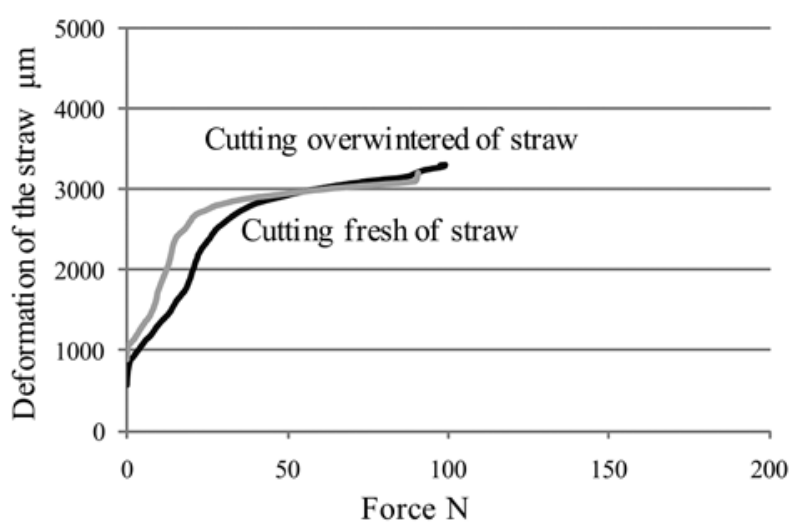

Figure 14. Cutting forces and deformations of fresh and overwintered straw of spring barley at the node $\left(\mathrm{LSD}_{05}\right.$ cutting overwintered of straw -6.8 , cutting fresh of straw - 3.6)

with the soil and environmental factors, residue decomposition processes of different intensity are in progress. The overwintered crop residues of lower cutting or breaking characteristics can make less influence on the technological operation processes of the disc coulters of agricultural drilling machinery, when sustainable agricultural technologies are applied in spring. 


\section{Conclusions}

1. Most often soil, environment and energy sustaining tillage and drilling technologies use disc coulters which can cut, break or press crop residues into the notch made by the coulter in the soil while interacting with the soil surface.

2. In terms of breaking force, the crop residues of winter wheat are stronger compared with those of spring barley. About $160 \mathrm{~N}$ force is needed to break the fresh straw of winter wheat without or with nodes, whereas, to break the analogous spring barley straw - about $53 \mathrm{~N}$ force.

3. The characteristics of the winter wheat and spring barley crop residues left to overwinter vary unevenly. The force for breaking the overwintered winter wheat straw decreases by about 3.2 times compared with the fresh straw of winter wheat and the force for breaking the straw of overwintered spring barley decreases by only $34 \%$.

4. The cutting of the fresh and overwintered crop residues of winter wheat and spring barley at the node and other section of the straw differs signally. To cut the fresh straw of winter wheat at the node about 125 $\mathrm{N}$ force (about $77 \mathrm{~N}$ for spring barley) is required and to cut the overwintered straw - about $30 \%$ (about $18 \%$ for spring barley) is needed. To cut the fresh straw of winter wheat at some other section about $160 \mathrm{~N}$ force (about $120 \mathrm{~N}$ for spring barley) is required; and about $13 \%$ less force is required for overwintered straw (about 17\% for spring barley).

5. In all cases the straw of both winter wheat and spring barley deforms less and more slowly at the node compared to the straw without the node.

\section{Acknowledgments}

The paper presents research findings, obtained through postdoctoral fellowship (No. 004/38). It was funded by European Union Structural Funds' project "Postdoctoral Fellowship Implementation in Lithuania". This work also was part of the long-term research programme "Productivity and Sustainability of Agricultural and Forest Soils" implemented by Lithuanian Research Centre for Agriculture and Forestry.

Received 30012013 Accepted 11062013

\section{References}

Arvidsson J. 2010. Energy use efficiency in different tillage systems for winter wheat on a clay and silt loam in Sweden. European Journal of Agronomy, 33 (3): 250-256 http://dx.doi.org/10.1016/j.eja.2010.06.003

Arvidsson J., Keller T., Gustafsson K. 2004. Specific draught for mouldboard plough, chisel plough and disc harrow at different water contents. Soil Tillage Research, 79: 221$232 \mathrm{http}: / / \mathrm{dx}$.doi.org/10.1016/j.still.2004.07.010

Bakasėnas A. 2008. Comparative analysis of energy input in presowing soil tillage and crop sowing. Žemès ùkio inžinerija, 40 (3-4): 5-15 (in Lithuanian)

Crawley M. J. 2007. The R book, 942 p. http://dx.doi.org/10.1002/9780470515075

Fan R., Zhang X., Liang A., Shi X., Chen X., Bao K., Yang X., Jia S. 2012. Tillage and rotation effects on crop yield and profitability on a Black soil in northeast China. Canadian Journal of Soil Science, 92: 463-470 http://dx.doi.org/10.4141/cjss2010-020
Galedar N. M., Jafari A., Mohtasebi S. S., Tabatabaeefar A., Sharifi A., O'Dogherty J. M., Rafiee S., Richard G. 2008. Effects of moisture content and level in the crop on the engeneering properties of alfalfa stems. Biosystems Engineering. 101: 199-208

http://dx.doi.org/10.1016/j.biosystemseng.2008.07.006

Germanas L. 2008. Evaluation indeles of sowing by disc coulters. Žemès ūkio inžinerija, 40 (3-4): 16-25 (in Lithuanian)

Grabber J. H. 2005. Haw do lignin composition, structure and cross-linking affect degradability? A review of cell wall model studines. Crop Science, 45: 820-831

http://dx.doi.org/10.2135/cropsci2004.0191

Hazarika S., Parkinson R., Bol R., Dixon L., Russell P., Donovan S., Allen D. 2009. Effect of tillage system and straw management on organic matter dynamics. Agronomy for Sustainable Development. 29: 525-533 http://dx.doi.org/10.1051/agro/2009024

Ince A., Ugurluay S., Guzel E., Ozcan T. M. 2005. Bending and shearing characteristics of sunflower stalk residue. Biosystems Engineering. 92: 175-181 http://dx.doi.org/10.1016/j.biosystemseng.2005.07.003

Kriaučiūnienė Z., Velička R., Raudonius S. 2012. The influence of crop residues tipe on their decomposition rate in the soil: a litterbag study. Zemdirbyste-Agriculture, 99 (3): 227-236

Kushwaha R. L., Vaishnav A. S., Zoberg G. C. 1986. Soil bin evaluation of disc coutlers under no-till crop residue conditions. American Society of Agricultural Enginieers. Transactions of ASAE, 29: 40-44

Linke C. 2006. Entwicklung der Direktsaat. Landtechnik, 61: 312-313 (in German)

Liu J., Chen Y., Lobb D. A., Kushwaha R. L. 2007. Soil-strawtillage tool interaction: field and soil bin study using one and three sweeps. Canadian Biosystems Engineering, 47: $2.1-2.6$

Liu J., Chen Y., Kushwaha R. L. 2010. Effect of tillage speed and straw length on soil and straw movement by a sweep. Soil and Tillage Research, 109: 9-17 http://dx.doi.org/10.1016/j.still.2010.03.014

Magalhaes P. S. G., Bianchini A., Braunbeck O. A. 2007. Simulated and experimental analyses of a toothed rolling coulter for cutting crop residues. Biosystems Engineering, 96: (2) 193-200 http://dx.doi.org/10.1016/j.biosystemseng.2006.10.014

Mahmoodi E., Jafari A. 2010. Influential parameters for designing and power consumption calculating of cumin mower. Australian Journal of Crop Science, 4 (3): 142-149

O’Dogherty M. J., Huber J. A., Dyson J., Marshall C. J. A. 1995. A study of the physical and mechanical properties of wheat straw. Journal of Agricultural Engineering Research, 62 (2): 133-142 http://dx.doi.org/10.1006/jaer.1995.1072

Šarauskis E., Köller K., Butkus V. 2005. Research on technological parameters to determine the design factors of direct drilling coulters for sugar beets. Lanbauforschung Volkenrode, 3: 171-180

Sarauskis E. 2008. The investigations of cutting straw with active disc sowing ploughshares. Žemès ūkio inžinerija, 40 (1): 17-29 (in Lithuanian)

Šarauskis E., Buragienè S., Romaneckas K., Sakalauskas A., Jasinskas A., Vaiciukevičius E., Karayel D. 2012. Working time, fuel consumption and economic analysis of different tillage and sowing systems in Lithuania: proceedings of $11^{\text {th }}$ international scientific conference Engineering for Rural Development. Jelgava, Latvia, p. 52-59

Tarakanovas P., Raudonius S. 2003. Agronominių tyrimų duomenų statistinè analizè taikant kompiuterines programas ANOVA, STAT, SPLIT-PLOT i paketo SELEKCIJA ir IRRISTAT. Lithuanian University of Agriculture, $58 \mathrm{p}$. (in Lithuanian)

Tavakoli H., Mohtasebi S. S., Jafari A. 2009. Effects of moisture content, internode position and loading rate on the bending characteristics of barley straw. Research in Agricultural Engineering, 55 (2): 45-51 
ISSN 1392-3196 / e-ISSN 2335-8947

Zemdirbyste-Agriculture, vol. 100, No. 3 (2013), p. 269-276

DOI 10.13080/z-a.2013.100.034

\title{
Žieminių kviečių bei vasarinių miežių šiaudų nutraukimo ir perpjovimo jègos poreikis
}

\author{
E. Šarauskis ${ }^{1}$, L. Masilionyte $\dot{1}^{1,2}$, A. Andriušis ${ }^{1}$, A. Jakštas ${ }^{1}$ \\ ${ }^{1}$ Aleksandro Stulginskio Universitetas \\ ${ }^{2}$ Lietuvos agrarinių ir miškų mokslų centro Joniškèlio bandymų stotis
}

\section{Santrauka}

Taikant dirvą, aplinką ir energiją tausojančias žemės dirbimo bei sėjos technologijas, sudėtingèja žemės dirbimas ir sèklų ịterpimas. Žemès dirbimo ir sẻjos mašinų darbui didelę ịtaką daro dirvos paviršiuje liekančios augalinès liekanos. Jos trukdo žemès dirbimui, ypač sėjos noragėlių darbui. Taikant dirvą, aplinką ir energiją tausojančias žemès dirbimo bei sejos technologijas dažniausiai naudojami diskiniai noragèliai, kurie sąveikaudami su dirva augalines liekanas gali perpjauti, nutraukti arba įspausti ị noragèlio išbrèžtą vagutę. Tyrimų tikslas - ištirti žemės dirbimo bei sẻjos mašinų darbui darančias ịtaką rudeninių ir peržiemojusių žieminių kviečių bei vasarinių miežių šiaudų nutraukimo ir perpjovimo jègas. Augalinių liekanų perpjovimo ir nutraukimo eksperimentiniai tyrimai atlikti 2011-2012 m. Aleksandro Stulginskio universiteto Tribologijos laboratorijoje. Tyrimų metu naudoti $22 \%$ drègnio rudenị šviežiai nupjauti ir $5 \%$ drègnio peržiemoję su bambliu ir be bamblio žieminių kviečių bei vasarinių miežių šiaudai.

Tyrimų metu nustatyta, kad vasarinių miežių augalines liekanas galima nutraukti lengviau nei žieminių kviečių. Rudeniniams su bambliu ir be bamblio žieminių kviečių šiaudams nutraukti reikia maždaug $160 \mathrm{~N}$ jègos, o analogiškiems vasarinių miežių šiaudams $-53 \mathrm{~N}$ jẻgos. Nutraukimo savybėms didelę įtaką daro augalinių liekanų palikimas žiemoti dirvos paviršiuje. Tačiau tyrimų rezultatai parodė, kad per žiemą paliktų žieminių kviečių ir vasarinių miežių augalinių liekanų nutraukimo savybès kito nevienodai. Peržiemojusių žieminių kviečių šiaudų nutraukimo jèga sumažejo maždaug 3,2 karto, lyginant su rudeniniais šiaudais, o peržiemojusių vasarinių miežių šiaudų nutraukimo jẻga sumažejo tik apie 34 \%. Augalinių liekanų pjovimo diskinị noragèlị imituojančiu peiliu tyrimų rezultatai parodè, kad rudeninių ir peržiemojusių žieminių kviečių bei vasarinių miežių augalinių liekanų perpjovimas ties bambliu ir kitoje šiaudo vietoje žymiai skiriasi. Rudeniniams žieminių kviečių ir vasarinių miežių šiaudams perpjauti ties bambliu reikia nuo 35 iki $43 \mathrm{~N}$ mažiau jègos nei pjaunat kitoje šiaudo vietoje. Peržiemojusiems vasarinių miežių ir žieminių kviečių šiaudams perpjauti ties bambliu reikia nuo 18 iki $30 \%$ mažesnès jègos nei šių augalų rudeniniams šiaudams. Žieminių kviečių ir vasarinių miežių šiaudai pjovimo metu ties bambliu deformuojasi mažiau ir lèčiau nei lygūs šiaudai be bamblio.

Reikšminiai žodžiai: augalinès liekanos, noragèlis, nutraukimo jèga, pjovimo jèga, vasariniai miežiai, žieminiai kviečiai. 